University of Nebraska - Lincoln

DigitalCommons@University of Nebraska - Lincoln

Publications, Agencies and Staff of the U.S.

Department of Commerce

U.S. Department of Commerce

2009

Health Assessment of Weddell Seals, Leptonychotes weddellii, in

McMurdo Sound, Antarctica

P.K. Yochem

Hubbs-Sea World Research Institute, San Diego

B.S. Stewart

Hubbs-Sea World Research Institute, San Diego

T.S. Gelatt

NOAA Fisheries, NMML, Seattle, WA,

D.B. Siniff

University of Minnesota, St. Paul

Follow this and additional works at: https://digitalcommons.unl.edu/usdeptcommercepub

Part of the Environmental Sciences Commons

Yochem, P.K.; Stewart, B.S.; Gelatt, T.S.; and Siniff, D.B., "Health Assessment of Weddell Seals, Leptonychotes weddellii, in McMurdo Sound, Antarctica" (2009). Publications, Agencies and Staff of the U.S. Department of Commerce. 203.

https://digitalcommons.unl.edu/usdeptcommercepub/203

This Article is brought to you for free and open access by the U.S. Department of Commerce at DigitalCommons@University of Nebraska - Lincoln. It has been accepted for inclusion in Publications, Agencies and Staff of the U.S. Department of Commerce by an authorized administrator of DigitalCommons@University of Nebraska - Lincoln. 


\title{
Chapter 7 \\ Health Assessment of Weddell Seals, \\ Leptonychotes weddellii, in McMurdo Sound, Antarctica
}

\author{
P.K. Yochem, B.S. Stewart, T.S. Gelatt, and D.B. Siniff
}

\subsection{Introduction}

The demography of Weddell seals in eastern McMurdo Sound, Antarctica, has been well studied during the past three decades (e.g. Stirling 1971; Siniff et al. 1977; Testa and Siniff 1987; Hastings and Testa 1998; Gelatt et al. 2001). Detailed life-history data are available on thousands of seals tagged as pups in McMurdo Sound, making this population a rich resource for wildlife health studies because health parameters can be evaluated in the light of reproductive histories and genetic relationships of several generations of tagged seals.

Recently, evidence of exposure to diseases generally associated with domestic animals and feral wildlife has been detected in Antarctic wildlife (Austin and Webster 1993; Olsen et al. 1996; Gardner et al. 1997; Retamal et al. 2000; Foster et al. 2002) and this has generated concern and debate regarding the risks of disease introduction to Antarctic wildlife. Antibodies to viruses that have caused large die-offs in phocids in other areas of the world have been detected in Weddell seals (Bengtson et al. 1991), and there is a historical report of a mass die-off of crabeater seals that may have had a viral etiology (Laws and Taylor 1957).

We examined and collected biomedical samples from Weddell seals (Leptonychotes weddellii) during studies of post-breeding-season foraging behaviour of adults and movements of weaned pups as a complement to ongoing studies on the ecology and population dynamics of the McMurdo seals (Stewart et al. 2000, 2003). Here we report on Weddell seal health assessments conducted during the $1996 / 97,1997 / 98$ and 1998/99 breeding seasons at the Delbridge Islands $\left(77.68^{\circ} \mathrm{S}\right.$,

P.K. Yochem and B.S. Stewart

Hubbs-Sea World Research Institute, San Diego, CA, USA

e-mail: PYochem@hswri.org; BStewart@hswri.org

T.S. Gelatt

NOAA Fisheries, NMML, Seattle, WA, USA

D.B. Siniff

Dept. Ecology, Evolution \& Behavior, University of Minnesota, St. Paul, MN, USA 
$\left.166.50^{\circ} \mathrm{E}\right), \mathrm{McMurdo}$ Sound, Antarctica. Our objectives were to compile baseline biomedical data for Weddell seals in McMurdo Sound, and to identify infectious and non-infectious diseases affecting the population. Development of such a database, including information on normal background morbidity and mortality, is an important first step in evaluating natural versus anthropogenic impacts on population health (Geraci et al. 1999; Reddy et al. 2001). These data will be integral to international studies of southern ocean pinnipeds that seek to evaluate the influence of biotic and abiotic factors on the ecology of these apex predators.

\subsection{Methods}

Seals that appeared to be healthy were observed for several minutes while resting prior to initiation of physical restraint (Fig. 7.1). Respiratory rate was obtained by counting chest excursions for 2-5 min; heart rate was obtained, where possible, by observing the left lateral chest wall just behind the fore flipper for the slight movement associated with each heartbeat. The body was scanned for obvious abnormalities such as fresh wounds or nasal discharge. Animals were captured and handled using standard techniques (Stirling 1966; Cline et al. 1969); head bags (Fig. 7.2) were used for all adults (some animals were first captured in a hoop net) and for some larger pups. Seals were examined by a veterinarian and were measured (standard length and axillary girth). Physical examinations included evaluation of the musculoskeletal system (symmetry, lesions) and cardiopulmonary system (heart rate, mucous membrane colour, respiratory rate and character). The integument was examined for evidence of moult, wounds or other lesions. Eyes, ears, nares and oral cavity were inspected for discharges or lesions such as corneal ulcers and broken teeth. Hydration was estimated by visual inspection of mucous membranes, skin turgor and tears. The urogenital and gastrointestinal systems were evaluated opportunistically by examining urine or faeces and by visual inspection for lesions at urogenital openings. Examination of the nervous system consisted of a limited evaluation of animals' vision, hearing, cranial nerve function (e.g. blink reflex) and peripheral nerve function (e.g. flinching when rear flippers were touched) in response to the activities of handlers. Blood samples were collected from the extradural vein or from the interdigital vessels of the rear flippers of all seals; faecal samples were collected opportunistically from a subset of seals (17 adults, 3 weaned pups). Satellite-linked radio-transmitters and other telemetry instruments were glued to the dorsal pelage of some seals (Fig. 7.2). A subset of animals was sedated with intra-vascular injections of diazepam (mean dosage $=0.07 \mathrm{mg} \mathrm{kg}^{-1}$; s.d. $=0.02 \mathrm{mg} \mathrm{kg}^{-1}$ ) immediately following blood sample collection to facilitate attachment of instruments.

Forty-six adults (14 males, 32 females), 15 weaned pups ( 8 males, 7 females) and 20 nursing pups ( 8 males, 12 females) were examined and sampled. In addition, a random sample of 214 seals was surveyed for lesions (as described by McFarlane 1996) without being handled.

Preliminary haematological evaluation was conducted at the Crary Laboratory at McMurdo Station, Antarctica, and included determination of haematocrit and 


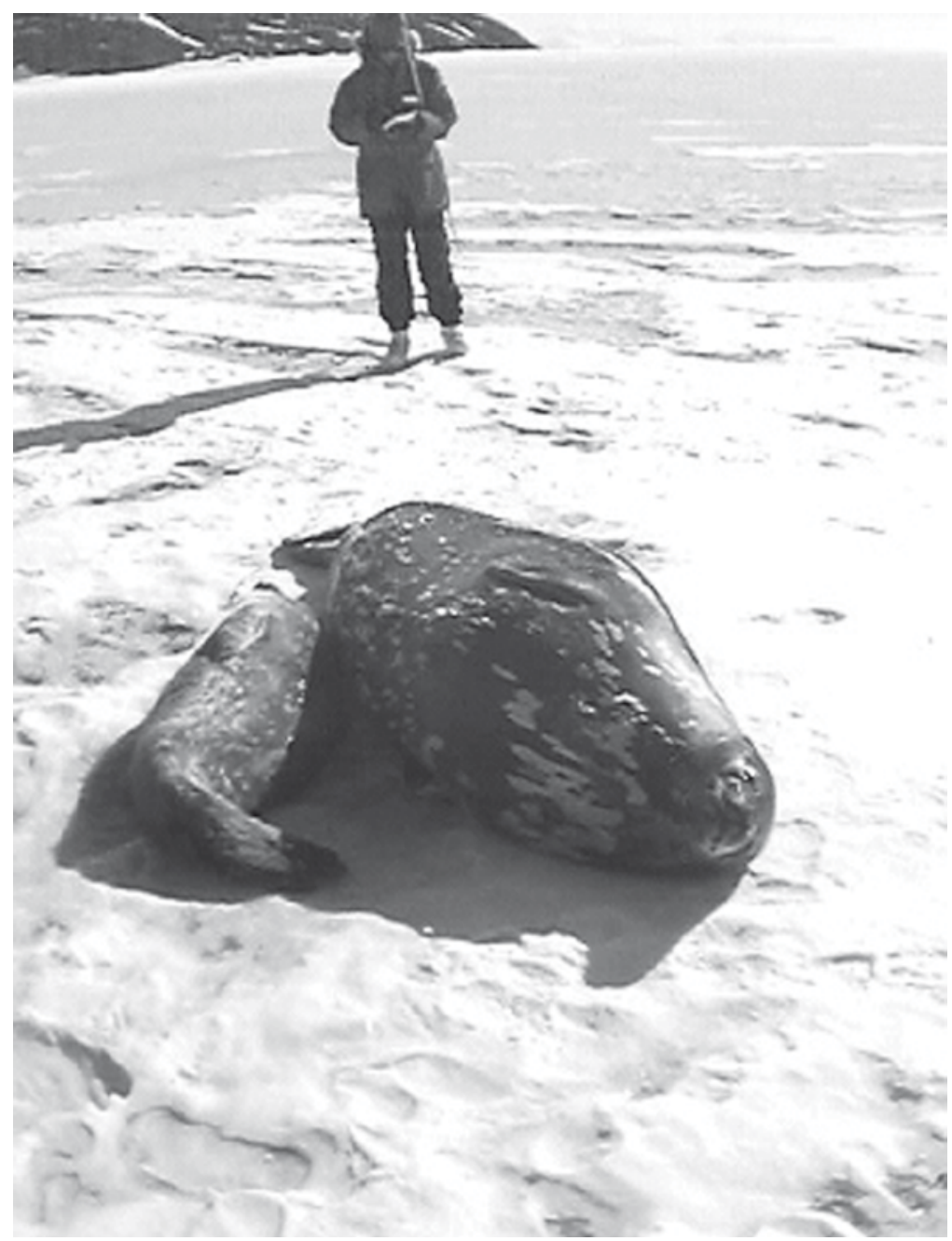

Fig. 7.1 Resting Weddell seal female and pup being examined prior to capture for biomedical sample collection

description of serum quality. Red and white blood cell counts were obtained using the Unopette system and a haemacytometer. Haemoglobin was evaluated with a BMS haemoglobinometer. Blood smears were air-dried and preserved for transport to the Hubbs-SeaWorld Research Institute laboratory in San Diego, California (USA), where they were stained for microscopic examination and differential count of white blood cells (band neutrophils, mature neutrophils, lymphocytes, monocytes, eosinophils and basophils), morphology of red and white blood cells and subjective evaluation of platelet number. In all, 11 haematological parameters were measured. 


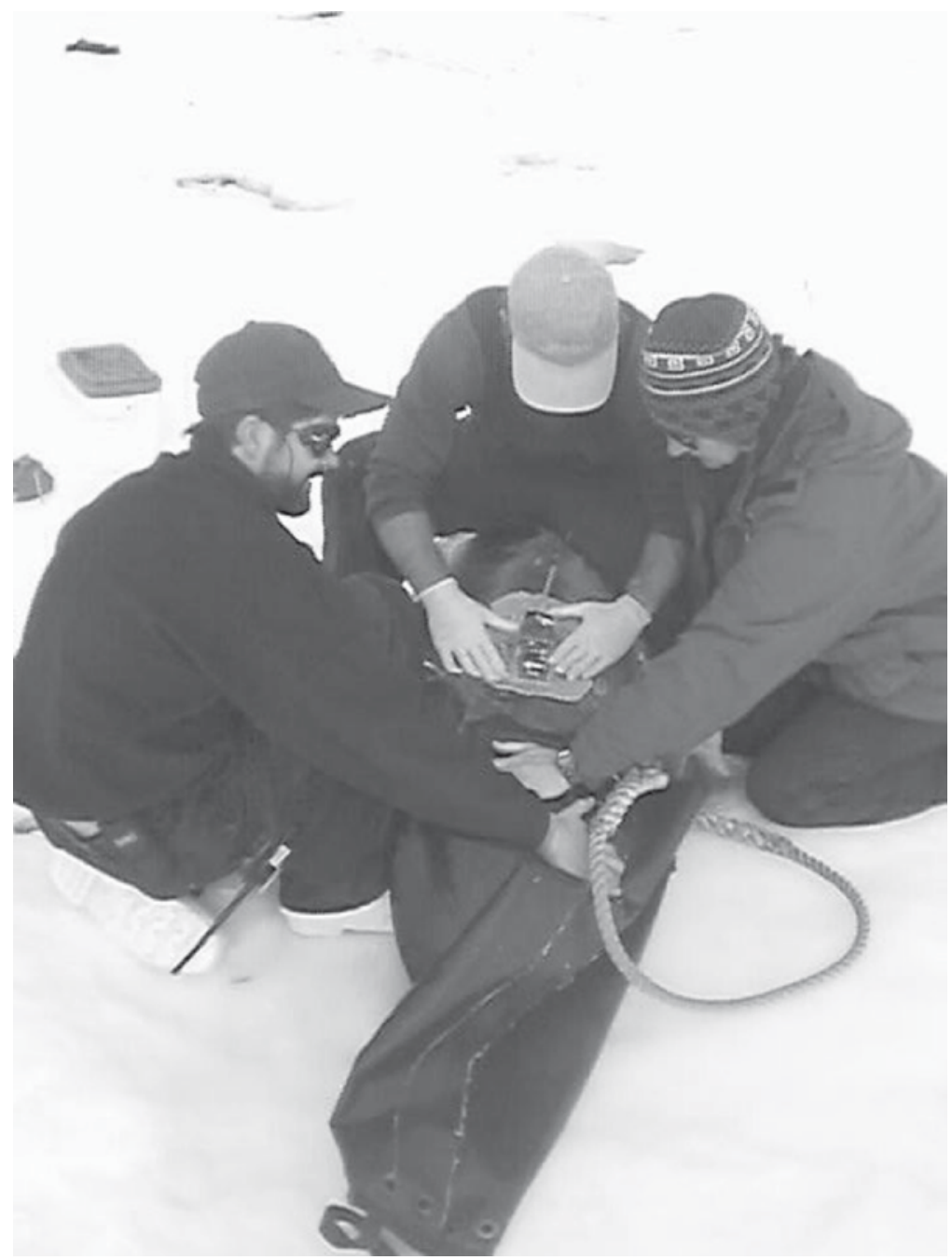

Fig. 7.2 Satellite-linked radio-transmitter being glued to the dorsal pelage of a physically restrained Weddell seal

77 Serum was stored in ultralow freezers $\left(-70\right.$ to $\left.80^{\circ} \mathrm{C}\right)$ for several weeks and trans78 ported on dry ice prior to U.S. laboratory evaluation. Biochemical assays were 79 performed by the SeaWorld San Diego Animal Care Laboratory, San Diego, 80 California. Twenty parameters were measured, including markers for liver, kidney 81 and muscle disease (alanine aminotransferase, aspartate aminotransferase, total 82 bilirubin, gamma glutamyltransferase, blood urea nitrogen, creatine kinase, lactate 83 dehydrogenase), body condition and nutritional status (glucose, cholesterol, triglycerides, 
total protein), inflammation/infection (albumin, globulin, alkaline phosphatase, serum iron) and electrolytes (sodium, potassium, chloride) and other ions (calcium, phosphorus). Haematological and serum biochemical parameters were evaluated for age/sex class differences using Kruskal-Wallis ANOVA; differences are reported as significant if $p<0.05$.

Faecal examinations (consistency, colour, presence of blood or mucous, presence and identity of parasites) by direct smear and faecal flotation were conducted at the Crary Laboratory, McMurdo Station.

Serological assays for antibodies to selected bacterial and viral pathogens were conducted by the California Animal Health and Food Safety Laboratory System, Davis, California (Brucella sp., Leptospira sp.) and the Okalahoma Animal Disease Diagnostic Laboratory, Stillwater, Oklahoma (canine distemper virus, phocine distemper virus, dolphin morbillivirus, porpoise morbillivirus).

\subsection{Results}

Abnormal findings from physical examination were recorded for 21 of 81 (26\%) animals handled during the course of this study (Table 7.1a); some seals had more than one lesion. Abnormalities included 1 adult that began shivering within 5 min of capture, 8 adults with very worn or broken teeth, 1 pup with an inspiratory wheeze and bilateral nasal discharge, and 11 seals ( 8 adults, 3 pups) with fresh puncture wounds. Ocular lesions were observed in three adults. There were no significant $(p<0.05)$ differences in serum biochemical parameters between animals with normal versus abnormal physical findings; however, animals with abnormal physical findings had significantly more band neutrophils and mature neutrophils, and fewer lymphocytes than normal seals. Clinically healthy pups were significantly larger (length and girth) than pups that were abnormal on physical examination.

Haematologic and serum chemistry values recorded by age and sex are presented in Table 7.2. Adults differed significantly from pups (weaned and nursing) for 14 parameters. Adults had more band neutrophils and eosinophils, as well as higher creatinine, total bilirubin, alanine aminotransferase, sodium and chloride levels. Pups had more lymphocytes and higher glucose, cholesterol, calcium, phosphorus and serum iron. There was no significant difference in haematocrit between adults and pups, but weaned pups had higher haematocrits than nursing pups. Although there was no significant difference in triglycerides between weaned pups and adults, nursing pups had significantly higher triglyceride levels than either weaned pups or adults. Nursing pups also had higher total protein levels and globulin levels than adults or weaned pups; albumin levels were higher in weaned pups than in either adults or nursing pups.

No sex differences were detected for any of the biochemical parameters measured. However, statistically significant differences were noted for some haematological parameters, and these differences were present in both adults and pups: males had lower haematocrits, lower red blood cell counts and more band neutrophils than females. 
Table 7.1 Lesions and other sources of morbidity recorded during visual inspections (214 seals) or veterinary medical examinations (81 seals) of Weddell seals in McMurdo Sound

(a) Lesions and other abnormalities detected during veterinary medical examinations of 81 seals handled for biomedical sampling. Abnormalities were recorded from 21 of 81 (26\%) seals; some seals had more than one lesion

\begin{tabular}{|c|c|c|c|c|}
\hline \multirow[b]{2}{*}{ Lesion/abnormality } & \multicolumn{2}{|c|}{ Adults } & \multicolumn{2}{|c|}{ Pups } \\
\hline & $\begin{array}{l}\text { Males } \\
(n=14)\end{array}$ & $\begin{array}{l}\text { Females } \\
(n=32)\end{array}$ & $\begin{array}{l}\text { Males } \\
(n=16)\end{array}$ & $\begin{array}{c}\text { Females } \\
(n=19)\end{array}$ \\
\hline $\begin{array}{l}\text { Fresh skin lesion(s), minor (e.g. puncture } \\
\text { wound) }\end{array}$ & $5(36 \%)$ & $3(9 \%)$ & $2(13 \%)$ & $1(5 \%)$ \\
\hline Worn or broken teeth & $4(29 \%)$ & $4(13 \%)$ & 0 & 0 \\
\hline Ocular pathology (corneal opacity) & $2(14 \%)$ & $1(3 \%)$ & 0 & 0 \\
\hline Inspiratory wheeze & 0 & 0 & 0 & $1(5 \%)$ \\
\hline Purulent bilateral nasal discharge & 0 & 0 & 0 & $1(5 \%)$ \\
\hline Shivering & $1(7 \%)$ & 0 & 0 & 0 \\
\hline \multicolumn{5}{|c|}{$\begin{array}{l}\text { (b) Lesions and other abnormalities recorded during visual surveys of } 214 \text { randomly selected } \\
\text { Weddell seals. Abnormalities were noted for } 75 \text { of } 214(35 \%) \text { seals; some seals had more than one } \\
\text { lesion }\end{array}$} \\
\hline Lesion/abnormality & $\begin{array}{l}\text { Adult males } \\
(n=42)\end{array}$ & $\begin{array}{l}\text { Adult females } \\
(n=119)\end{array}$ & \multicolumn{2}{|c|}{ Weaned pups $(n=53)$} \\
\hline Pup ill-health & 0 & 0 & \multicolumn{2}{|c|}{$13(25 \%)$} \\
\hline Fresh skin lesion(s), minor & $9(21 \%)$ & $23(19 \%)$ & \multicolumn{2}{|l|}{$2(4 \%)$} \\
\hline Fresh skin lesion(s), major & $10(24 \%)$ & $7(6 \%)$ & \multicolumn{2}{|l|}{0} \\
\hline Worn or broken teeth & $11(26 \%)$ & $9(8 \%)$ & \multicolumn{2}{|l|}{0} \\
\hline $\begin{array}{l}\text { Ocular pathology (e.g. corneal opacity, } \\
\text { punctured globe) }\end{array}$ & $3(7 \%)$ & $7(6 \%)$ & \multicolumn{2}{|l|}{$1(2 \%)$} \\
\hline Respiratory disease & $1(2 \%)$ & $2(2 \%)$ & \multicolumn{2}{|l|}{$3(6 \%)$} \\
\hline Firm nodule on thorax & 0 & $1(1 \%)$ & \multicolumn{2}{|l|}{0} \\
\hline Healed fracture, foreflipper & $1(2 \%)$ & 0 & \multicolumn{2}{|l|}{0} \\
\hline
\end{tabular}

No parasites were detected during examinations of blood smears or during direct examinations of fresh faecal smears. Faecal floatations revealed ova from both anisakid nematodes and diphyllobothrid cestodes in 11 of 17 (65\%) adult seals. Anisakid nematode ova were found in only 3 of 17 (18\%) adults. Diphyllobothrid cestode ova were found in only 3 of 17 (18\%) adults and 2 of $3(67 \%)$ weaned pups. No parasite ova were detected in 2 of 17 (12\%) adults and 1 of $3(33 \%)$ weaned pups.

Visual surveys of 214 randomly selected Weddell seals (42 adult males, 119 adult females, 53 weaned pups; Table 7.7b) revealed the following lesions or other sources of morbidity: pup ill-health (lethargy, malnourishment; 13 animals), fresh skin lesions/wounds (34 minor, 17 major), severely worn or cracked teeth (20 animals), ocular pathology (11 animals), and respiratory disease (6 animals). One animal had a firm nodule on its thorax, and one appeared to have a healed fracture of one foreflipper. Some seals had more than one lesion.

No serum antibodies were found in any seal for Brucella sp., Leptospira sp. or the four morbilliviruses (canine distemper virus, phocine distemper virus, dolphin morbillivirus, porpoise morbillivirus). 


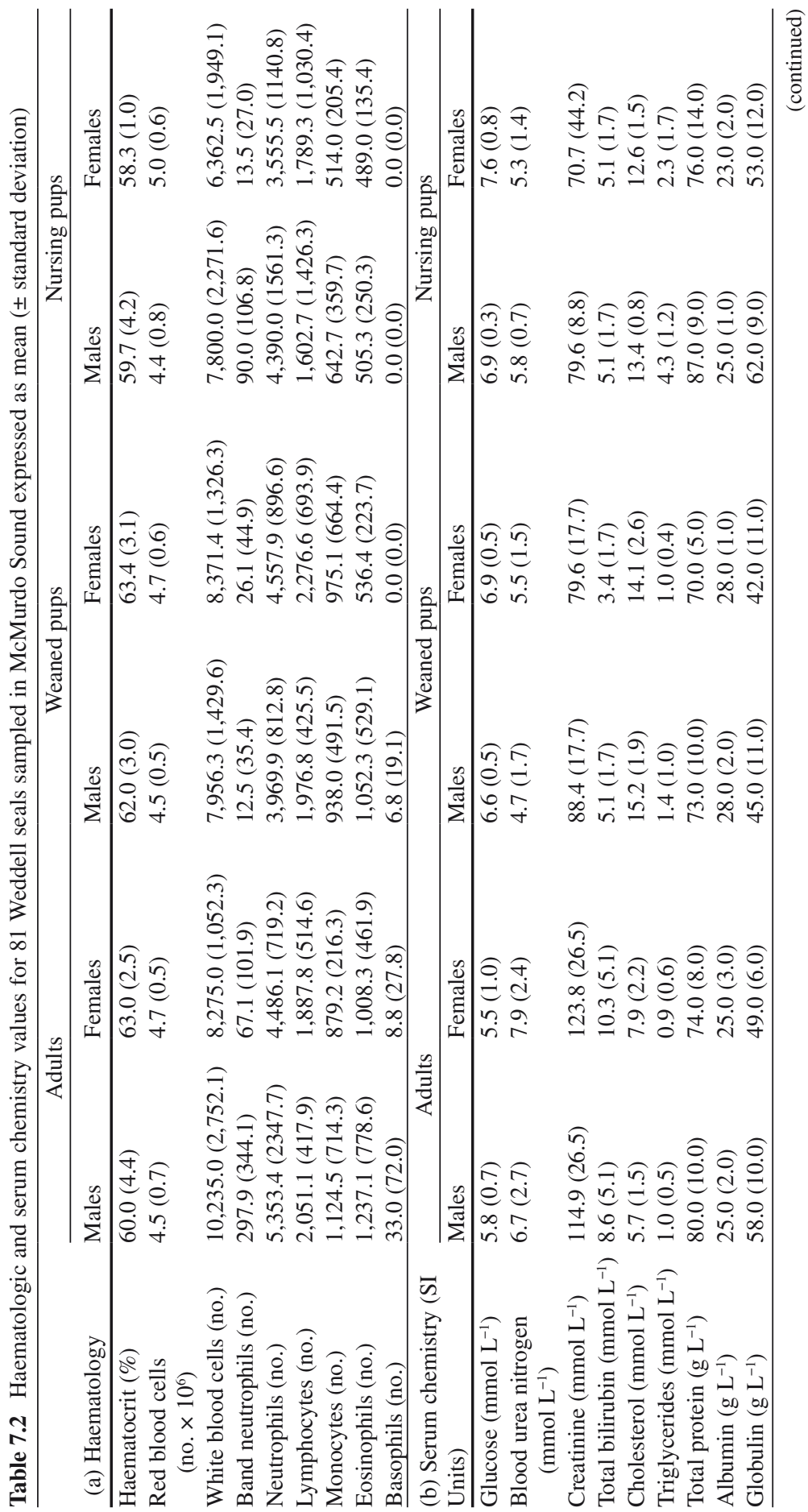




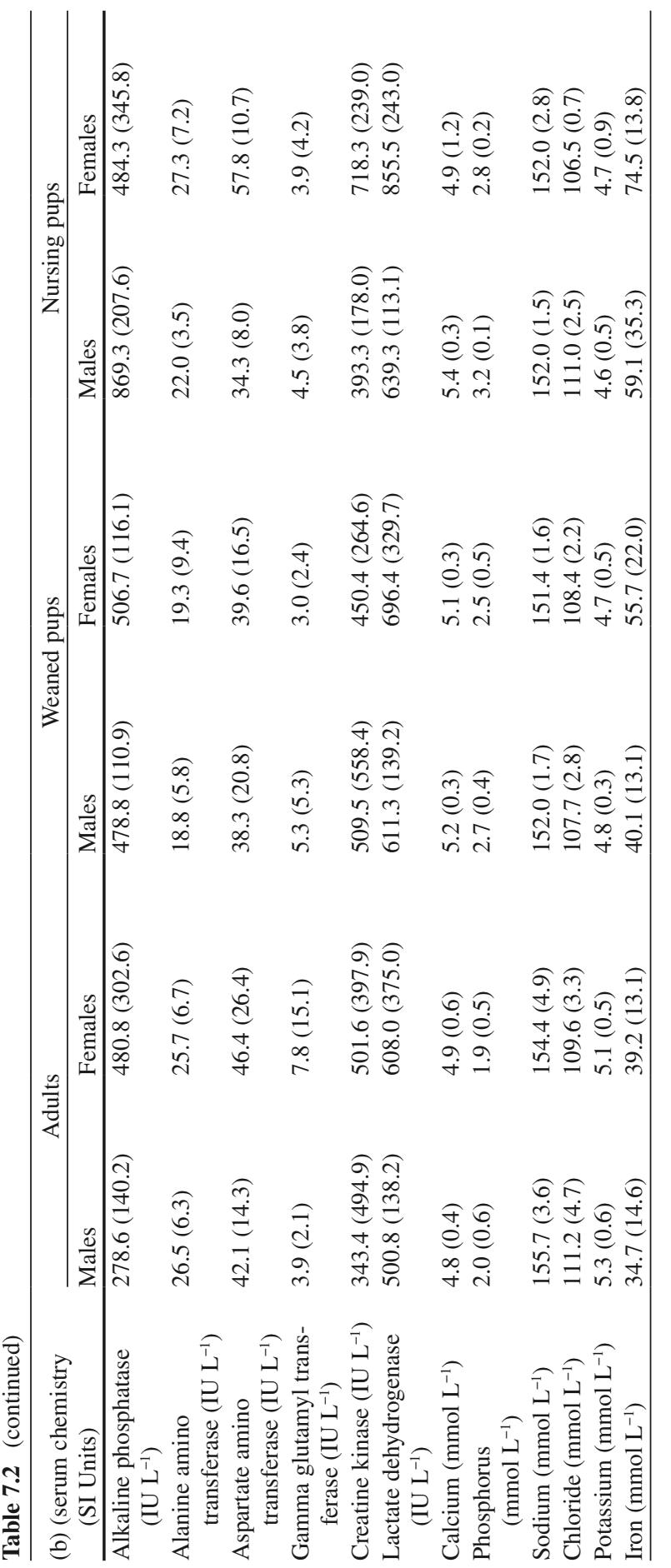




\subsection{Discussion}

\subsubsection{Haematology and Serum Chemistry}

Seal et al. (1971) and Schumacher et al. (1992) have presented data for a number of biochemical parameters in Weddell seal blood; the values we measured were consistent with those reported by these authors (exceptions noted below) and were generally within reference ranges known for other phocid seals. Variability in haematology and serum or plasma biochemistry in pinnipeds, including Weddell seals, has been correlated with many factors, including age (Bryden and Lim 1969; Seal et al. 1971; Lane et al. 1972; Horning and Trillmich 1997; Hall 1998; Sepulveda et al. 1999; Lewis et al. 2001; Nordøy and Thoreson 2002), sex (Poulin et al. 1994; Lewis et al. 2001), diet (Kuiken 1985; Thompson et al. 1997), habitat (e.g. coastal vs. offshore dolphins, Duffield et al. 1983), diving ability (e.g. deep-diving vs. shallow-diving species; Vallyathan et al. 1969; Hedrick and Duffield 1991), air temperature (Poulin et al. 1994), physiologic state (e.g. pregnancy, lactation, malt, fasting vs. feeding; Worthy and Lavigne 1982; Poulin et al. 1994; Lewis et al. 2001; Englehard et al. 2002), handling (St Aubin et al. 1979) and condition (Geraci et al. 1979; Roletto 1993).

Some of the age and sex class differences in haematological and serum biochemical parameters we observed in Weddell seals have been reported previously in Weddell seals or other pinnipeds. Seal et al. (1971) also measured higher creatinine levels in adult versus young Weddell seals. Nordøy and Thoresen (2002) reported higher sodium levels and lower calcium levels in harp seal adults than in pups; we observed the same differences in Weddell seals. Although Hall (1998) did not sample adults, she did report higher glucose levels in pups than in yearling grey seals; we observed higher glucose levels in pups than in adults. We observed higher haematocrits in weaned than in nursing pups; this has been reported by other researchers for Galapagos fur seals (Horning and Trillmich 1997) and southern elephant seals (Lewis et al. 2001). Packed cell volume is often used interchangeably with haematocrit (Willard et al. 1999); Sepulveda et al. (1999) reported higher packed cell volume in juveniles than in pups (Juan Fernandez fur seals). Although we did not detect significant differences in haematocrits between adults and pups, others have reported conflicting data on these differences: Sepulveda et al. (1999) found that packed cell volumes of adult females were lower than those of juveniles (Juan Fernandez fur seals), whereas Bryden and Lim (1969) and Lane et al. (1972) found higher haematocrits in adults than in pups.

The nursing Weddell seal pups we sampled had higher total protein levels and globulin levels than adults or weaned pups. Seal et al. (1971) and Nordøy and Thoresen (2002), however, reported higher globulin levels in adults than pups for Weddell seals and harp seals, respectively. Sepulveda et al. (1999) reported higher plasma proteins in juveniles than pups for Juan Fernandez fur seals.

No sex differences were detected for any of the biochemical parameters we measured. However, we did find statistically significant differences for some haematological parameters, and these differences were present in both adults and pups: 
males had lower haematocrits, lower red blood cell counts, and more band neutrophils than females. Although male Weddell seals had more neutrophils than females, there was no significant difference between the sexes in the total white blood cell count. Poulin et al. (1994), however, did report higher white blood cell counts in males than in females. Lewis et al. (2001) reported lower haemoglobin levels in males than in females. While there was no significant difference in haemoglobin levels in the males and females we sampled, males did have lower values for two other measures of oxygen-carrying capacity of the blood, haematocrit and red blood cell count.

\subsubsection{Macroparasites}

A wide variety of endoparasites and ectoparasites have been reported in Weddell seals and other Antarctic phocids (Beverley-Burton 1971; Drozda 1987; Orecchia et al. 1994; Wojciechowska and Zdzitowiecki 1995; Mehlhorn et al. 2002). We did not detect any previously unreported nematodes or cestodes in the Weddell seals we examined, and none of these animals had clinical signs consistent with gastrointestinal or respiratory parasitism (e.g. diarrhea, cough). Parasite infections in marine mammals, even when infestations are heavy, often do not have a significant impact on otherwise healthy hosts and may be considered incidental or secondary findings (Baker 1989; Duszynski et al. 1998 cited in Dailey 2001; Geraci et al. 1999; Dailey 2001; Gulland et al. 2001). Parasites may cause morbidity and even mortality in some cases (Gerber et al. 1993; Roletto 1993; Geraci et al. 1999; Dailey 2001), although this may be due primarily to concurrent secondary bacterial infection (as in verminous pneumonia, Dailey 2001). Gastrointestinal protozoa have been reported in Antarctic and sub-Antarctic pinnipeds (Drozda 1987; Duszynski et al. 1998 cited in Dailey 2001), but we did not detect them in the fresh faecal smears we examined. However, protozoal parasite ova and cysts are frequently missed with a single faecal smear (Willard et al. 1999); examination of multiple samples, collected 1-2 weeks apart, is generally recommended before an animal is considered negative for protozoal parasites.

\subsubsection{Bacteria and Viruses}

As with macroparasites (nematodes, cestodes, trematodes), the presence of bacteria and viruses is not always correlated with clinical disease. However, bacteria and viruses may have been responsible for mass die-offs, particularly where large populations of social or seasonally gregarious species have been exposed to new pathogens to which they have no herd immunity. Although no Weddell seals tested positive for Brucella sp. or morbillivirus in our study, others have reported the presence of antibodies to these and other pathogens in Antarctic phocids 
(Bengtson et al. 1991; Stenvers et al. 1992; Retamal et al. 2000). We did not detect leptospirosis in any of the Weddell seals we tested. Although leptospirosis has not been reported to date in pinnipeds in the Southern Hemisphere, it has caused epizootics among pinnipeds in other areas (Vedros et al. 1971). Other serosurveys have demonstrated little exposure to other viruses in Weddell seals and other Antarctic phocids. Truyen et al. (1995) surveyed over 200 adult and 10 juvenile Weddell seals for influenza viruses and paramyxovirus but found no positives. Stenvers et al. (1992) reported no antibodies against phocine distemper virus in Weddell seals, although they did detect high neutralizing titres to seal and feline herpes virus. No antibodies to either herpes virus or distemper virus were detected in crabeater seals by Stenvers et al. (1992).

Our seroprevalence data suggest that the McMurdo Weddell seal population is relatively naïve with respect to pathogen exposure, suggesting that it may be vulnerable to disease outbreaks such as those that have caused large die-offs of marine mammals in other regions. The die-off of crabeater seals reported by Laws and Taylor (1957) affected over $85 \%$ of the local population (over 1,500 seals in the Antarctic Peninsula region). Barrett (1999) noted that the population size of Antarctic crabeater seals (several million) would be adequate to maintain a morbillivirus in circulation once introduced; it has been estimated that at least 300,000 individuals are necessary to maintain the human morbillivirus, measles, in the population (Black 1991). Such large numbers are needed because the virus is maintained by infecting new susceptible hosts. Grenfell et al. (1992), examining the long-term consequences of the 1988 morbillivirus epizootic in North Atlantic phocids, stated that the seal population would have to recover for at least 10 years before another outbreak was likely; it appears that this was an accurate calculation, as the most recent (2002) outbreak occurred 13-14 years after the previous one. Jensen et al. (2002) noted that testing in the 10 years leading up to the 2002 phocine distemper outbreak in Europe demonstrated $95 \%$ seronegativity in the harbour seal population; all positives were newly-weaned pups, suggesting that these were passive/maternal antibodies. The authors noted that this was an indication that the virus had not been circulating in the population and that the recent (2002) reappearance of phocine distemper virus into this largely susceptible population could allow rapid spread with devastating consequences, as was observed during the 1988 outbreak that killed over 18,000 animals. Van Bressem et al. (2001) noted that decreased seroprevalence to morbillivirus detected over time in two species of odontocete cetaceans made them susceptible to new epizootics, as the virus was not becoming endemic in the population and animals were losing their humoral immunity.

Harwood and Hall (1990) reviewed marine mammal epizootics and their population effects. The factors responsible for emergence or resurgence of a viral disease are often difficult to determine (Miller et al. 2001); often a change in host range is implicated (Truyen et al. 1995). Innate differences among species in immune response (and therefore resistance) to morbilliviruses have been reported in phocids (Duignan et al. 1997). Duignan et al. (1995) proposed that enzootic infection may become established in one species (grey seals), facilitated by factors such as large population size, high annual recruitment, and innate resistance to the virus, and 
then be maintained in another less abundant and/or less resistant species (harbour seals) through casual contact with the first species.

\subsubsection{Starvation and Physical Injury}

Common and important causes of morbidity and mortality in pinnipeds include starvation and malnourishment (particularly of neonates and newly weaned pups), conspecific trauma, and predation (Tierney 1977; Baker and McCann 1989; Steiger et al. 1989; Banish and Gilmartin 1992; Cooper 1996; McFarlane 1996; Baker et al. 1998; Geraci et al. 1999; Gulland et al. 2001; Lucas et al. 2003). Physical injury caused by inter-specific and intra-specific interactions has long been recognised as an important source of non-infectious disease in free-ranging wildlife, including marine mammals (Cooper 1996). The clinical significance of a physical injury to an individual animal depends upon the severity of the injury (including the area of the body affected) and the presence or absence of secondary conditions (e.g. haemorrhage, infection; Cooper 1996; Gulland et al. 2001). Cooper (1996, p. 163) noted that '...clinical signs [of trauma] can range from coma to an almost complete absence of abnormalities.' In the Weddell seals we examined, pup ill health (lethargy, malnourishment) and physical trauma were the most common findings. However, most of the wounds we examined in Weddell seals appeared to be the result of interactions with conspecifics (e.g. male fighting) rather than inter-specific or predatory wounds. The Delbridge Islands in McMurdo Sound are surrounded by fast-ice during the breeding season, when our disease surveys were made. Predators such as leopard seals and killer whales generally do not move into the area until the ice begins to break up and/or icebreakers have opened up a channel into McMurdo Station several months after the peak of the breeding season. Ocular pathology (e.g. corneal oedema, cataracts) was observed in $5 \%$ of the seals we examined, and is commonly reported in other stranded and free-ranging pinnipeds (Stoskopf et al. 1985; Schoon and Schoon 1992; Gerber et al. 1993). Severely worn or cracked teeth were observed in $6 \%$ of the seals we examined (all adults), and this has been identified as a mortality factor in Weddell seals (Stirling 1969); Weddell seals' teeth are important for maintaining breathing holes in the ice.

\subsection{Conclusions}

Baseline biomedical data such as those reported here, combined with information on life history and behaviour (e.g. migratory behaviour), are important for elucidating patterns of infection and risk within and between populations and for interpreting toxicological data (Duignan et al. 1995; Gelatt et al. 1999; Geraci et al. 1999). Geraci et al. (1999, p. 368) noted that 'only by understanding the causes and patterns of normal mortality can we recognise unusual events and determine their cause and impacts on a population...' 
Acknowledgements We thank the staff of the National Science Foundation office in Christchurch, New Zealand, the Crary Laboratory at McMurdo Station, Antarctic Support Associates, Raytheon Polar Services and the pilots and staff of Petroleum Helicopters, Inc. for logistic support in McMurdo Sound. The research was supported by grants from the National Science Foundation (OPP-9420818 and OPP-9725820 to DB Siniff), Hubbs-SeaWorld Research Institute, Busch Entertainment Corporation (Anheuser-Busch Corporation) and Chevron-Texaco. We thank Mike Cameron, Dan Monson, Kyler Abernathy and Sharon Melin for field and laboratory assistance and the SeaWorld San Diego Animal Care Laboratory for performing or consulting on haematological and serum biochemical assays. The research was permitted under the Marine Mammal Protection Act and the Antarctic Conservation Act, and was reviewed and approved by the Institutional Animal Care and Use Committees of Hubbs-SeaWorld Research Institute and the University of Minnesota.

\section{References}

Austin FJ, Webster RG (1993) Evidence of ortho- and paramyxoviruses in fauna from Antarctica. J Widl Dis 29(4):568-571

Baker JR (1989) Natural causes of death in non-suckling grey seals (Halichoerus grypus). Vet Rec 125(20):500-503

Baker JR, McCann TS (1989) Pathology and bacteriology of adult male Antarctic fur seals, Arctocephalus gazella, dying at Bird Island, South Georgia. Br Vet J 145:263-275

Baker JR, Jepson PD, Simpson VR, Kuiken T (1998) Causes of mortality and nonfatal conditions among grey seals (Halichoerus grypus) found dead on the coasts of England, Wales and the Isle of Man. Vet Rec 142:595-601

Banish LD, Gilmartin WG (1992) Pathological findings in the Hawaiian monk seal. J Wildl Dis 28:428-434.

Barrett T (1999) Morbillivirus infections, with special emphasis on morbilliviruses of carnivores. Vet Microbiol 69:3-13

Bengtson JL, Boveng P, Franzen U, Heide-Jorgensen MP, Harkonen T (1991) Antibodies to canine distemper virus in Antarctic seals. Mar Mamm Sci 7:85-87

Beverley-Burton M (1971) Helminths from the Weddell seal, Leptonychotes weddelli (Lesson, 1826), in the Antarctic. Can J Zool 49(1):75-83

Black FL (1991) Epidemiology of paramyxoviridae. In: Kingsbury D (ed) The paramyxoviruses. Plenum, New York, pp 509-536

Bryden MM, Lim HK (1969) Blood parameters of the southern elephant seal (Mirounga leonina Linn.) in relation to diving. Comp Biochem Physiol 28:139-148

Cline DR, Siniff DB, Erickson AW (1969) Immobilizing and collecting blood from Antarctic seals. J Wildl Manage 33:138-144

Cooper JE (1996) Physical injury. In: Fairbrother A, Locke LN, Hoff GL (eds). Noninfectious disease of wildlife, 2nd edn. Iowa State University Press, Ames, pp 157-172

Dailey MD (2001) Parasitic diseases. In: Dierauf LA, Gulland FMD (eds). CRC handbook of marine mammal medicine, 2nd edn. CRC, Boca Raton, Fl, pp 357-379

Drozda J (1987) Oocysts of six new Coccidomorpha species from pinnipeds of King George Island (South Shetlands, Antarctic). Acta Protozool 26:263-266

Duffield DA, Ridgway SH, Cornell LH (1983) Hematology distinguishes coastal and offshore forms of dolphins (Tursiops). Can J Zool 61:930-933

Duignan PJ, Saliki JT, St Aubin DJ, Early G, Sadove S, House JA, Kovacs K, Geraci JR (1995) Epizootiology of morbillivirus infection in North American harbor seals (Phoca vitulina) and gray seals (Halichoerus grypus). J Wildl Dis 31:491-501

Duignan PJ, Duffy N, Rima BK, Geraci JR (1997) Comparative antibody response in harbour and grey seals naturally infected by a morbillivirus. Vet Immunol Immunopathol 55:341-349

Duszynski DW, Upton SJ, Couch L (1998) Coccidia (Eimeriidae) of marine mammals (cetacean, pinnipeds, sirenia). In: Coccidia of the world, NSF Grant PEET DEB 9521687. Cited in Dailey 2001 
Engelhard GH, Hall AJ, Brasseur SMJM, Reijnders PJH (2002) Blood chemistry in southern elephant seal mothers and pups during lactation reveals no effect of handling. Comp Biochem Physiol Pt A 133:367-378

Foster G, MacMillan AP, Godfroid J, Howie F, Ross HM, Cloeckaert A, Reid RJ, Brew S, Patterson IAP (2002) A review of Brucella sp. infection of sea mammals with particular emphasis on isolates from Scotland. Vet Microbiol 90:563-580

Gardner H, Brouwer S, Gleeson L, Kerry K, Riddle M (1997) Poultry virus infection in Antarctic penquins. Nature 387:245

Gelatt TS, Arendt T, Murphy MS, Siniff DM (1999) Baseline levels of selected minerals and fatsoluble vitamins in Weddell seals (Leptonychotes weddellii) from Erebus Bay, McMurdo Sound, Antarctica. Mar Poll Bull 38:1251-1257

Gelatt, TS, Davis CS, Siniff DB, Strobeck C (2001) Molecular evidence for twinning in Weddell seals (Leptonychotes weddellii). J Mamm 82:491-499

Geraci JR, St Aubin DJ, Smith TG (1979) Influence of age, condition, sampling time, and method on plasma chemical constituents in free-ranging ringed seals, Phoca hispida. J Fish Res Brd Can 36:1278-1282

Geraci JR, Harwood J, Lounsbury VJ (1999) Marine mammal die-offs: causes, investigations, and issues. In: Twiss Jr. JR, Reeves RR (eds) Conservation and management of marine mammals. Smithsonian Institution Press, Washington DC, pp 367-395

Gerber JA, Roletto J, Morgan LE, Smith Data Manager, Gage LJ (1993) Findings in pinnipeds stranded along the central and northern California coast, 1984-1990. J Wildl Dis 29:423-433

Grenfell BT, Lonergan ME, Harwood J (1992) Quantitative investigations of the epidemiology of phocine distemper virus (PDV) in European common seal populations. Science Total Environ 115:15-29

Gulland FMD, Haulena M, Dierauf LA. (2001) Seals and sea lions. In: Dierauf LA, Gulland FMD (eds) CRC handbook of marine mammal medicine, 2nd edn. CRC, Boca Raton, FL, pp 907-926

Hall AJ (1998) Blood chemistry and hematology of gray seal (Halichoerus grypus) pups from birth to postweaning. J Zoo Wildl Med 29(4):401-407

Harwood J, Hall A (1990) Mass mortality in marine mammals: its implication for population dynamics and genetics. TREE 5:254-257

Hastings KK, Testa JW (1998) Maternal and birth colony effects on survival of Weddell seal offspring from McMurdo Sound, Antarctica. J Anim Ecol 67:722-740

Hedrick MS, Duffield DA (1991) Haematological and rheological characteristics of blood in seven marine mammal species: physiological implications for diving behaviour. J Zool (Lond) 225:273-283

Horning M, Trillmich F (1997) Development of hemoglobin, hematocrit and erythrocyte values in Galapagos fur seals. Mar Mamm Sci 13:100-113

Jensen T, van de Bildt M, Dietz HH, Anderson TH, Hammer AS, Kuiken T, Osterhaus ADBE (2002) Another phocine distemper outbreak in Europe. Science 297:209

Kuiken T (1985) Influences of diet, gestation and age on haematology and plasma chemistry of the harbour seal, Phoca vitulina. Aquat Mamm 11:40

Lane RAB, Morris RJH, Sheedy JW (1972) A haematological study of the southern elephant seal, Mirounga leonina (Linn.). Comp Biochem Physiol 42A:841-850

Laws RM, Taylor RJF (1957) A mass dying of crabeater seals, Lobodon carcinophagus (gray). Proc Zool Soc Lond 129(3):315-324

Lewis M, Campagna C, Uhart M, Ortiz CL (2001) Ontogenetic and seasonal variation in blood parameters in southern elephant seals. Mar Mamm Sci 17:862-872

Lucas Z, Daoust PY, Conboy G, Brimacombe M (2003) Health status of harp seals (Phoca groenlandica) and hooded seals (Cystophora cristata) on Sable Island, Nova Scotia, Canada, concurrent with their expanding range. J Wildl Dis 39:16-28

McFarlane RA (1996) Gross pathology of the Weddell seal (Leptonychotes weddelli) in the Vestfold Hills, East Antarctica. Aquat Mamm 22(1):27-33 
Mehlhorn B, Mehlhorn H, Plotz J (2002) Light and scanning electron microscopical study on Antarctophthirius ogmorhini lice from the Antarctic seal Leptonychotes weddelli. Parasitol Res 88:651-660

Miller DL, Ewing RY, Bossart GD. (2001) Emerging and resurging diseases. In: Dierauf LA, Gulland FMD (eds) CRC handbook of marine mammal medicine, 2nd edn. CRC, Boca Raton, FL, pp 15-30

Nordøy ES, Thoresen SI (2002) Reference values for serum biochemical parameters in freeranging harp seals. Vet Clin Pathol 31(3):98-105

Olsen BB, Bergstrom S, McCafferty DJ, Sellin M, Wistrom J (1996) Salmonella enteriditis in Antarctica: zoonosis in man or humanosis in penguins? Lancet 348:1319-1320

Orecchia P, Mattiucci S, D’Amelio S, Paggi L, Plotz J, Cianchi R, Nascetti G, Arduino P, Bullini L (1994) Two new members in the Contracaecum osculatum complex (Nematoda, Ascaridoidea) from the Antarctic. Int J Parasitol 24:367-377

Poulin DJ, Lavigne DM, Ronald K (1994) Changes in leukocyte concentrations in grey seals (Halichoerus grypus) in relation to temperature and photoperiod. J Therm Biol 19:63-73

Reddy, ML, Dierauf LA, Gulland FMD. (2001) Marine mammals as sentinels of ocean health. In: Dierauf LA Gulland FMD (eds) CRC handbook of marine mammal medicine, 2nd edn. CRC, Boca Raton, FL, pp 3-13

Retamal P, Blank O, Abalos P, Torres D (2000) Detection of anti-Brucella antibodies in pinnipeds from the Antarctic Territory. Vet Rec 146:166-167

Roletto J (1993) Hematology and serum chemistry values for clinically healthy and sick pinnipeds. J Zoo Wildl Med 24(2):145-157

Schoon HA, Schoon D (1992) Lenticular lesions in harbour seals (Phoca vitulina). J Comp Pathol 107:379-388

Schumacher U, Rauh G, Plotz J, Welsch U (1992) Basic biochemical data on blood from Antarctic Weddell seals (Leptonychotes weddelli): ions, lipids, enzymes, serum proteins and thyroid hormones. Comp Biochem Physiol 102A:449-451

Seal US, Erickson AW, Siniff DB, Cline DR (1971) Blood chemistry and protein polymorphisms in three species of Antarctic seals (Lobodon carcinophagus, Leptonychotes weddellii, and Mirounga leonina)In: Burt WH (ed) Antarctic pinnipedia. Ant Res Ser 8: 181-192

Sepulveda MS, Ochoa-Acuna H, Homer BL (1999) Age-related changes in hematocrit, hemoglobin and plasma protein in Juan Fernandez fur seals (Arctocephalus philippii). Mar Mamm Sci 15:575-581

Siniff DB, DeMaster DP, Hofman RJ, Eberhardt LL (1977) An analysis of the dynamics of a Weddell seal population. Ecol Monogr 47:319-335

St Aubin DJ, Austin TP, Geraci JR (1979). Effects of handling stress on plasma enzymes in harp seals, Phoca groenlandica. J Wildl Dis 15:569-572

Steiger GH, Calambokidis J, Cubbage JC, Skilling DE, Smith AW, Gribble DH (1989) Mortality of harbour seal pups at different sites in the inland waters of Washington. J Wildl Dis 25:319-328

Stenvers O, Plotz J, Ludwig H 1992. Antarctic seals carry antibodies against seal herpesvirus. Arch Virol 123:421-424

Stewart BS, Yochem PK, Gelatt TS, Siniff DB (2000) First year movements of Weddell seal pups in the western Ross Sea, Antarctica. In: Davison W, Williams CH, Broady P (eds) Antarctic ecosystems: models for a wider ecological understanding. New Zealand Natural Sciences, Canterbury University, NewZealand, pp 71-76

Stewart BS, Yochem PK, Gelatt TS, Siniff DB (2003) The pack ice niche of Weddell seals in the Ross Sea. In: Huiskes AHL, Gieskes WWC, Rozema J, Schorno RML, van der Vies SM, Wolff WJ (eds) Antarctic biology in a global context. Backhuys, Leiden, The Netherlands, pp 224-228

Stirling I (1966) A technique for handling live seals. J Mamm 47(3):543-544

Stirling I (1969) Tooth wear as a mortality factor in the Weddell seal (Leptonychotes weddelli). J Mamm 50(3):559-565

Stirling I (1971) Population aspects of Weddell seal harvesting at McMurdo Sound, Antarctica. Polar Rec 15:653-667 
Stoskopf MK, Zimmerman S, Hirst LW, Green R (1985) Ocular anterior segment disease in northern fur seals. J Am Vet Med Assoc 187:1141-1144

Testa JW, Siniff DB (1987) Population dynamics of Weddell seals (Leptonychotes weddellii) in McMurdo Sound, Antarctica. Ecology 57:149-165

Tierney TJ (1977) Disease and injury in the southern elephant seal. Aust Vet J 53:91-92

Thompson PM, Tollit DJ, Corpe HM, Reid RJ, Ross HM (1997) Changes in haematological parameters in relation to prey switching in a wild population of harbour seals. Funct Ecol 11:743-750

Truyen U, Parrish CR, Harder TC, Kaaden OR (1995) There is nothing permanent except change. The emergence of new virus diseases. Vet Microbiol 43:102-122

Vallyathan NV, George JC, Ronald K (1969) The harp seal, Pagophilus groenlandicus (Erxleben, 1777), V. Levels of haemoglobin, iron, certain metabolites and enzymes in the blood. Can J Zool 47:1193-1197

Van Bressem M, Waerebeek KV, Jepson PD, Raga JA, Duignan PJ, Nielsen O, Di Beneditto AP, Siciliano S, Ramos R, Kant W, Peddemors V, Kinoshita R, Ross PS, Lopez-Fernandez A, Evans K, Crespo E, Barrett T (2001) An insight into the epidemiology of dolphin morbillivirus worldwide. Vet Microbiol 81:287-304

Vedros NA, Smith AW, Schonewald J, Migaki J, Hubbard RC (1971). Leptospirosis epizootic among California sea lions. Science 172:1250-1251

Willard MD, Tvedten H, Turnwald GH (1999) Small animal clinical diagnosis by laboratory methods, 3rd edn. Saunders, Philadelphia

Williams R, Bryden MM (1993) Observations of blood values, heart rate and respiratory rate of leopard seals (Hydrurga leptonynx) (Carnivora:Phocidae). Aust J Zool 41:433-499

Wojciechowska A, Zdzitowiecki K (1995) Cestodes of Antarctic seals. Acta Parasitol 40(3):125-131

Worthy GAJ, Lavigne DM (1982) Changes in blood properties of fasting and feeding harp seal pups, Phoca groenlandica, after weaning. Can J Zool 60:58-592 